University of Nebraska - Lincoln

DigitalCommons@University of Nebraska - Lincoln

\title{
3-2014
}

\section{Nongeocentric axial dipole field behavior during the Mono Lake excursion}

\author{
Robert M. Negrini \\ California State University - Bakersfield, rnegrini@csub.edu \\ Daniel T. McCuan \\ California State University - Bakersfield \\ Robert A. Horton \\ California State University - Bakersfield \\ James D. Lopez \\ California State University - Bakersfield \\ William S. Cassata \\ Lawrence Livermore National Laboratory
}

See next page for additional authors

Follow this and additional works at: https://digitalcommons.unl.edu/usgsstaffpub

Part of the Geology Commons, Oceanography and Atmospheric Sciences and Meteorology Commons, Other Earth Sciences Commons, and the Other Environmental Sciences Commons

Negrini, Robert M.; McCuan, Daniel T.; Horton, Robert A.; Lopez, James D.; Cassata, William S.; Channell, James E.T.; Verosub, Kenneth L.; Knott, Jeffrey R.; Coe, Robert S.; Liddicoat, Joseph C.; Lund, Steven P.; Benson, Larry V.; and Sarna-Wojcicki, Andrei M., "Nongeocentric axial dipole field behavior during the Mono Lake excursion" (2014). USGS Staff -- Published Research. 781.

https://digitalcommons.unl.edu/usgsstaffpub/781

This Article is brought to you for free and open access by the US Geological Survey at DigitalCommons@University of Nebraska - Lincoln. It has been accepted for inclusion in USGS Staff -- Published Research by an authorized administrator of DigitalCommons@University of Nebraska - Lincoln. 


\section{Authors}

Robert M. Negrini, Daniel T. McCuan, Robert A. Horton, James D. Lopez, William S. Cassata, James E.T. Channell, Kenneth L. Verosub, Jeffrey R. Knott, Robert S. Coe, Joseph C. Liddicoat, Steven P. Lund, Larry V. Benson, and Andrei M. Sarna-Wojcicki 


\section{Journal of Geophysical Research: Solid Earth}

\section{RESEARCH ARTICLE \\ 10.1002/2013JB010846 \\ Nongeocentric axial dipole field behavior during the Mono Lake excursion}

Key Points:

- Oscillating flux centers drive magnetic field during Mono Lake excursion

- Mono Lake excursion is distinct from the Laschamp excursion

- VGP paths of MLE from far removed localities occupy three main clusters

Correspondence to:

R. M. Negrini,

rnegrini@csub.edu

\section{Citation:}

Negrini, R. M., et al. (2014),

Nongeocentric axial dipole field beha-

vior during the Mono Lake excursion,

J. Geophys. Res. Solid Earth, 119,

doi:10.1002/2013JB010846.

Received 18 NOV 2013

Accepted 3 MAR 2014

Accepted article online 10 MAR 2014

\author{
Robert M. Negrini ${ }^{1}$, Daniel T. McCuan ${ }^{1}$, Robert A. Horton ${ }^{1}$, James D. Lopez ${ }^{1}$, William S. Cassata ${ }^{2}$, \\ James E. T. Channell ${ }^{3}$, Kenneth L. Verosub ${ }^{4}$, Jeffrey R. Knott ${ }^{5}$, Robert S. Coe ${ }^{6}$, Joseph C. Liddicoat ${ }^{7}$, \\ Steven P. Lund ${ }^{8}$, Larry V. Benson ${ }^{9}$, and Andrei M. Sarna-Wojcicki ${ }^{10}$ \\ ${ }^{1}$ Department of Geological Sciences, California State University, Bakersfield, California, USA, ${ }^{2}$ Physical and Life Sciences \\ Directorate, Lawrence Livermore National Laboratory, Livermore, California, USA, ${ }^{3}$ Department of Geological Sciences, \\ University of Florida, Gainesville, Florida, USA, ${ }^{4}$ Department of Geology, University of California, Davis, California, USA, \\ ${ }^{5}$ Department of Geological Sciences, California State University, Fullerton, California, USA, ${ }^{6}$ Earth and Planetary Sciences, \\ University of California, Santa Cruz, California, USA, ${ }^{7}$ Department of Environmental Science, Barnard College, Columbia \\ University, New York, New York, USA, ${ }^{8}$ Department of Earth Sciences, University of Southern California, Los Angeles, \\ California, USA, ${ }^{9}$ Institute of Arctic and Alpine Research, University of Colorado Boulder, Boulder, Colorado, USA, \\ ${ }^{10}$ Tephrochronology Laboratory, United States Geological Survey, Menlo Park, California, USA
}

Abstract A new record of the Mono Lake excursion (MLE) is reported from the Summer Lake Basin of Oregon, USA. Sediment magnetic properties indicate magnetite as the magnetization carrier and imply suitability of the sediments as accurate recorders of the magnetic field including relative paleointensity (RPI) variations. The magnitudes and phases of the declination, inclination, and RPI components of the new record correlate well with other coeval but lower resolution records from western North America including records from the Wilson Creek Formation exposed around Mono Lake. The virtual geomagnetic pole (VGP) path of the new record is similar to that from another high-resolution record of the MLE from Ocean Drilling Program (ODP) Site 919 in the Irminger Basin between Iceland and Greenland but different from the VGP path for the Laschamp excursion (LE), including that found lower in the ODP-919 core. Thus, the prominent excursion recorded at Mono Lake, California, is not the LE but rather one that is several thousands of years younger. The MLE VGP path contains clusters, the locations of which coincide with nonaxial dipole features found in the Holocene geomagnetic field. The clusters are occupied in the same time progression by VGPs from Summer Lake and the Irminger Basin, but the phase of occupation is offset, a behavior that suggests time-transgressive decay and return of the principal field components at the beginning and end of the MLE, respectively, leaving the nonaxial dipole features associated with the clusters dominant during the excursion.

\section{Introduction}

Paleomagnetic excursions, like magnetic reversals, are enigmatic high-amplitude field variations that provide constraints on geodynamo behavior during transitional states [Gubbins, 1999; Lund et al., 2005; Roberts, 2008; Valet et al., 2008], especially the unresolved question of the relative contributions of the axial dipole and the nonaxial dipole fields [Valet et al., 2008]. In addition, paleomagnetic excursions potentially provide important refinements to late Pleistocene age control, and excursions have been linked to extinction events during a critical period for the study of paleoclimate and human evolution [Benson et al., 1998, 2013; Mellars, 2006; Valet and Valladas, 2010].

We present a high-resolution sedimentary record of the Mono Lake excursion (MLE) from Summer Lake, Oregon, USA (BB3-I core), and compare this record to a MLE record from Ocean Drilling Program (ODP) Site 919 from the Irminger Basin in the North Atlantic Ocean. Both records are based on back-to-back discrete samples, thereby avoiding smoothing associated with records from continuous u-channel samples [Roberts, 2006]. The sampling is also of unprecedented detail, with each record containing $>50$ samples collected within the MLE. The BB3-I record is new, whereas the ODP-919 record was published previously [Channell, 2006] both in discrete and u-channel form. The virtual geomagnetic pole (VGP) path for the unsmoothed, discrete sample version of the ODP-919 record is presented here for the first time.

The BB3-I core was taken from the depocenter of the Summer Lake Basin (Figure 1), a subbasin of pluvial Lake Chewaucan [Allison, 1982]. Earlier published works on a nearby core reported a record of the MLE [Negrini 


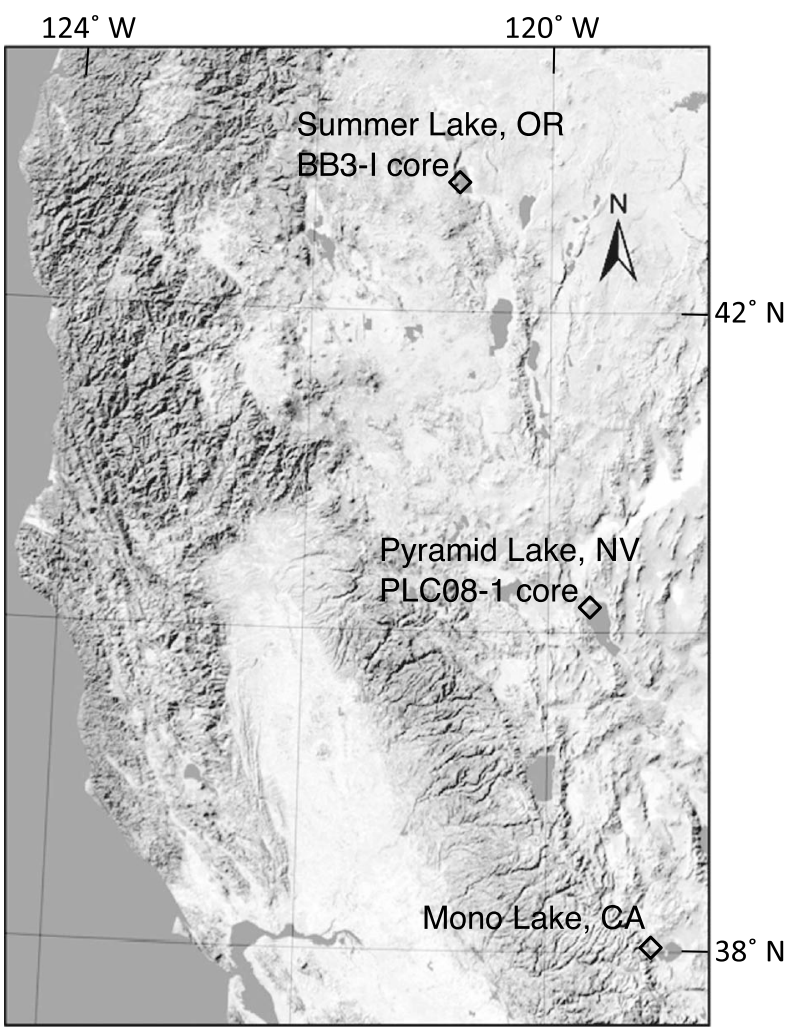

Figure 1. Location map with Great Basin lakes discussed in the text. et al., 2000; Zic et al., 2002]. However, these studies were completed using equipment whose sensitivity was comparable to the paleomagnetic signal during the excursion. Also, earlier studies lacked detailed rock magnetic analyses. Here we present an updated record from the Summer Lake Basin based on measurements made with a higher-precision magnetometer and modern rock magnetic instrumentation.

\section{Methods}

The $14.3 \mathrm{~m}$ long BB3-I core was taken from a hole located at $42.8057^{\circ} \mathrm{N}, 120.7831^{\circ} \mathrm{W}$ with a modified Livingston corer in liners consisting of $9.8 \mathrm{~cm}$ internal diameter (schedule 40) PVC pipe. Whole-core susceptibility was measured in the field with a Bartington MS2/MS2C meter/sensor combination immediately after core segments were retrieved from the coring rig, and the ends were secured with plastic wrap and duct tape. After transportation to cold storage at California State University, Bakersfield (CSUB), the core liners were cut in two places parallel to the core axis using a handheld circular saw. The core segments were subsequently split using potter's wire. Lithologic descriptions and core photographs were acquired shortly after splitting of the cores. Samples were taken from suspected volcanic ash beds for tephrochronological analyses and for radiocarbon dating of bulk organics. The grain size spectrum of subsamples was measured using a Malvern Mastersizer 2000 laser granulometer.

U-channel samples were extracted for reconnaissance paleomagnetic measurements using a 2-G Enterprises Model 755 rock magnetometer at the University of California, Davis, with measurements after alternating field demagnetization (AFD) at peak fields of $0,5,10,15,20$, and $25 \mathrm{mT}$. Discrete and oriented $5.1 \mathrm{~cm}^{3}$ samples were later extracted back-to-back from a subsection of the core found from the reconnaissance study to contain excursional directions. The natural remanent magnetization (NRM) of the discrete samples was measured using the same magnetometer at UC Davis after AFD at 0, 5, 10, 15, 20, 25, 30, 40, 50, 60, and $80 \mathrm{mT}$. A characteristic remanent magnetization (ChRM) was determined by applying principal component analysis to the four measurements [Kirschvink, 1980] between AFD steps of 25 and $50 \mathrm{mT}$ using the ZPlotit software written by G. Acton (2009 update). The low-field magnetic susceptibility of these samples was measured with a Bartington Instruments MS2/MS2B meter/sensor combination. Anhysteretic and isothermal remanent magnetizations (ARM, IRM) were also measured before and after AFD at 0, 10, 20, 30, 40, 50, 60, and $80 \mathrm{mT}$. The ARM bias and alternating field (AF) acquisition fields were 0.05 and $100 \mathrm{mT}$, respectively. The IRM acquisition field was $1.0 \mathrm{~T}$. Samples were fully demagnetized at peak fields of $100 \mathrm{mT}$ before laboratory magnetizations were imparted and measured.

Rock magnetic analyses were undertaken at the Institute for Rock Magnetism, University of Minnesota. The measurements include hysteresis loops with a Princeton Measurements Corporation vibrating sample magnetometer, backfield measurements for calculation of the $S$ ratio, and measurement of the anisotropy of magnetic susceptibility (AMS) using a Kappabridge KLY-2 instrument. Additional AMS measurements were conducted at the University of Southern California using a Kappabridge KLY-4S instrument.

Magnetic-mineral separates were prepared following the procedure outlined by McCabe et al. [1983], Wisniowiecki et al. [1983], and Horton et al. [1984]. The magnetic minerals were dried rapidly using acetone to prevent oxidation [Horton and Geissman, 1990]. The magnetic separates were analyzed in the CSUB X-ray 
Table 1. Major Elemental Analysis of Tephra Samples

\begin{tabular}{lcccccccccccc} 
Depth (mbgs) & Sample No. & $\mathrm{SiO}_{2}$ & $\mathrm{Al}_{2} \mathrm{O}_{3}$ & $\mathrm{Fe}_{2} \mathrm{O}_{3}$ & $\mathrm{TiO}_{2}$ & $\mathrm{Na}_{2} \mathrm{O}$ & $\mathrm{K}_{2} \mathrm{O}$ & $\mathrm{MgO}$ & $\mathrm{CaO}$ & $\mathrm{Cl}$ & Similarity Coefficient & Correlated Tephra \\
\hline 9.23 & $\mathrm{BB3} \mathrm{I}-4$ & 74.86 & 14.02 & 1.96 & 0.19 & 4.26 & 3.12 & 0.24 & 1.25 & 0.10 & $0.98-0.99$ & 0.97 \\
9.64 & $\mathrm{BB3} \mathrm{I}-5$ & 77.39 & 13.03 & 1.20 & 0.08 & 3.84 & 3.46 & 0.11 & 0.78 & 0.11 & Wono & Tephra G \\
13.7 & $\mathrm{BB3} \mathrm{I-7}$ & 76.54 & 13.96 & 1.19 & 0.09 & 3.84 & 2.50 & 0.24 & 1.56 & 0.08 & $0.97-0.98$ & Mount St. Helens Cy \\
\hline
\end{tabular}

${ }^{\mathrm{a}}$ Davis [1985].

${ }^{\mathrm{b}}$ Kuehan and Negrini [2010].

diffraction (XRD) laboratory using a $\mathrm{Cu} \mathrm{K} \alpha \mathrm{X}$-ray source and were examined using secondary electron imaging at the CSUB scanning electron microscopy (SEM) Laboratory. Polished rounds of magnetic separates were visually inspected using standard reflected-light microscopy. They were then examined with the SEM using backscattered electron imaging and were chemically analyzed using energy-dispersive X-ray spectroscopy (EDS); EDS analysis were compared with a magnetite standard. Due to limitations imposed by the electronbeam-interaction volume, only grains larger than $10 \mu \mathrm{m}$ were analyzed.

\section{Results}

\subsection{Age Control}

In previous studies, the MLE was found below Summer Lake tephra layer F (also known as the 34-30 cal ka B.P. Wono tephra) and Summer Lake tephra layer G, and above the 47-43 cal ka B.P. Mount St. Helens Cy tephra layer [Negrini et al., 2000; Kuehn and Negrini, 2010; Benson et al., 2013]. Based on major element geochemistry of glass shards, the tephra layers found at 9.23 and $9.64 \mathrm{~m}$ belowground surface (mbgs) in the BB3-I core are correlated with the Wono and $G$ tephra layers, respectively (Table 1). Their thicknesses $(1 \mathrm{~cm})$ and separation $(\sim 40 \mathrm{~cm})$ are consistent with those found in the nearby BB1 core [Negrini et al., 2000]. Also, these ash beds are graded. These observations imply that these two tephra layers are primary deposits derived from air fall into the lake.

The tephra layer found at 13.7 mbgs is correlated by major element glass shard composition to the Mount St. Helens Cy tephra layer (Table 1). In contrast to the Wono and G tephra layers, the Mount St. Helens Cy tephra layer was an order of magnitude thinner in the BB3-I core than in the BB1 core. Based on this dramatically different thickness, we conservatively infer that the Mount St. Helens Cy tephra layer in the BB3-I core was redeposited, and thus, it provides a maximum age of $47-43$ cal ka for sediment at $13.7 \mathrm{mbgs}$.

Twelve AMS radiocarbon dates from the interval containing and below the Wono tephra layer are summarized in Table 2 and Figure 2a. The raw ${ }^{14} \mathrm{C}$ age of the Wono tephra layer was determined by averaging two bracketing radiocarbon dates. The resulting age $\left(29.7 \pm 510{ }^{14} \mathrm{C}\right.$ kyr B.P.) is $3 \mathrm{kyr}$ older than that determined by radiocarbon dating from the Pyramid Lake core (PLC92B) as reported by Benson et al. [1997] but only $\sim 500$ years older than the uncalibrated age for the same tephra layer as determined in a newer core

Table 2. Radiocarbon Ages of Studied Samples

\begin{tabular}{|c|c|c|c|c|c|c|}
\hline Associated Figure & Laboratory \# & Depth (mbgs) & ${ }^{14} \mathrm{C}$ Age BP & Analysis Precision & Calibrated Age $2 \sigma \mathrm{min}$ & Calibrated Age $2 \sigma$ max \\
\hline Figure 2a & AA93986 & 9.04 & 29,440 & 370 & 33,183 & 34,766 \\
\hline Figure 2a & AA93987 & 9.46 & 28,980 & 350 & 32,607 & 34,593 \\
\hline Figure 2a & AA93988 & 10.10 & 21,700 & 270 & 25,126 & 26,798 \\
\hline Figure 2a & AA93989 & 10.47 & 30,360 & 400 & 34,106 & 36,268 \\
\hline Figure $2 \mathrm{a}$ & AA93990 & 11.04 & 31,420 & 450 & 34,988 & 36,675 \\
\hline Figure $2 a$ & AA93991 & 11.46 & 31,380 & 550 & 34,814 & 36,800 \\
\hline Figure 2a & AA93993 & 12.47 & 29,650 & 370 & 33,327 & 34,912 \\
\hline Figure $2 a$ & AA93994 & 12.97 & 39,500 & 1300 & 41,817 & 45,449 \\
\hline Figure $2 a$ & AA93995 & 13.52 & 42,700 & 1800 & 43,471 & 45,595 \\
\hline Figure 2a & AA93996 & 14.20 & 36,410 & 820 & 39,556 & 42,639 \\
\hline Figure $2 b$ & AA98607 & 0.10 & 2203 & 47 & & \\
\hline Figure $2 b$ & AA93982 & 0.52 & 2933 & 41 & & \\
\hline Figure $2 b$ & AA98608 & 1.28 & 3615 & 41 & & \\
\hline Figure $2 b$ & AA98609 & 1.84 & 4162 & 44 & & \\
\hline
\end{tabular}



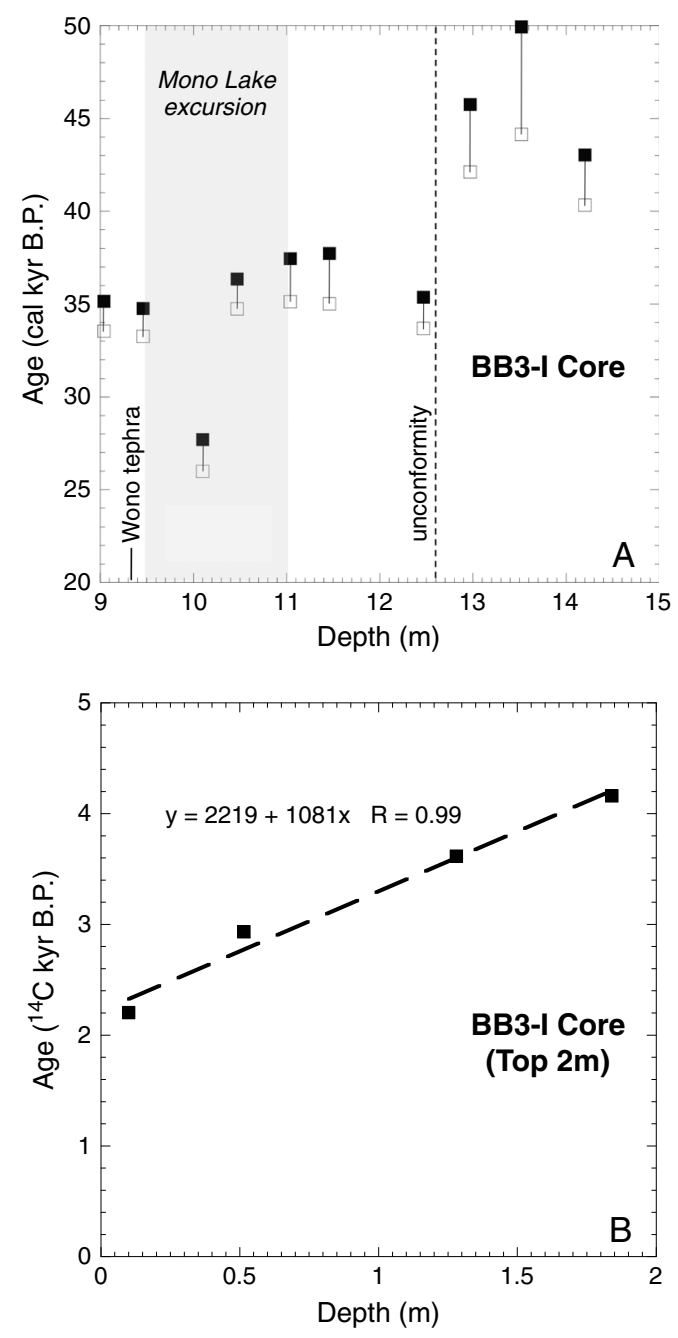

Figure 2. Age control for the BB3-I core. (a) Calibrated radiocarbon dates associated with the sedimentary magnetic records reported in this paper. Black and white boxes represent the maximum and minimum $2 \sigma$ ages, respectively, obtained using the Calib 6.1.1 calibration model with the INTCAL09 option [Stuiver et al., 2014]. Prior to calibration, a 500 year lake reservoir correction was subtracted. This represents a conservative (i.e., minimum) estimate for the reservoir effect (see text for further discussion). (b) Uncorrected radiocarbon dates from the top $2 \mathrm{~m}$ of the BB3-I core. The $2.2 \mathrm{kyr}$ age for the top of the core suggests that either the 500 year lake reservoir correction used in Figure $2 \mathrm{a}$ is an underestimate or that significant deflation of the lake bed surface has occurred. from Pyramid Lake, with dating based on correlation of paleomagnetic secular variation features with those from North Atlantic marine sediment cores [Benson et al., 2008, 2013]. These observations suggest that the lake reservoir effect of the BB3-I core is somewhere between 500 and $3000 \mathrm{kyr}$. This reservoir correction is consistent with the radiocarbon age of modern sediments in the Summer Lake Basin ( 2200 years) as determined by interpolating five Holocene radiocarbon ages to the top of BB3-I core (Figure 2b). We note that this conclusion presumes that there has been no significant deflation of the modern surface. Based on the above discussion, a conservative estimate of the lake reservoir effect, 500 years, was subtracted from raw ${ }^{14} \mathrm{C}$ ages before calibration. Because this is the minimum estimate of the lake reservoir effect and because the dates are on bulk organic matter, which is material that may have been redeposited [e.g., Abbott and Stafford, 1996], the resulting calibrated dates likely represent maximum ages.

\subsection{Sedimentology}

The sediments of the BB3-I core are dominantly fine silts (mean grain size $<15 \mu \mathrm{m}$ ) with rare thin fine sand layers, sometimes in the form of volcanic ash. A prominent unconformity was found at $12.6 \mathrm{mbgs}$ (Figure 3). The sediments below this unconformity are uniformly fine grained. The unconformity is marked by a coarse-grained layer which fines upward into laminated fine-grained lake sediments. The radiocarbon dates increase abruptly across this unconformity suggesting several thousand years of either nondeposition, or erosion of several thousand years of sediments at the unconformity, or more likely a combination of the two processes. As a result, there is no sedimentary and, hence, paleomagnetic record in the BB3-I core from $\sim 42$ to $\sim 37 \mathrm{ka}$ (Figure 2a).

\subsection{Sediment Magnetism}

We report here the paleomagnetic record below $9 \mathrm{~m}$ that includes the Wono tephra layer and the underlying MLE. The declination, inclination, and maximum angular deviation (MAD) associated with the ChRM are plotted in Figure 4. After AFD to $25 \mathrm{mT}$, the mean NRM intensity within the excursion interval ranged from

0.81 to $13 \mathrm{~mA} / \mathrm{m}$ with a mean and standard deviation of $6 \pm 3 \mathrm{~mA} / \mathrm{m}$ (Figure 4). The inclination of the minimum principal AMS axis was always greater than $70^{\circ}$ with few exceptions. The exceptions, presumably associated with sediment deformation, were always from the top few centimeters of core drives that contain sediment that had fallen into the open hole after removal of the core barrel. Reinspection of the core drive tops after oxidation enhanced the visibility of sedimentary features and revealed zones of displaced sediment (e.g., mismatched sediment color, high angle layering, etc.). The associated paleomagnetic samples were deleted from the final data set.

The shapes of hysteresis loops (Figure 5) suggest that the magnetic grain size distribution is uniform throughout the studied interval and is consistent with a magnetic mineralogy of (titano)magnetite. The latter 


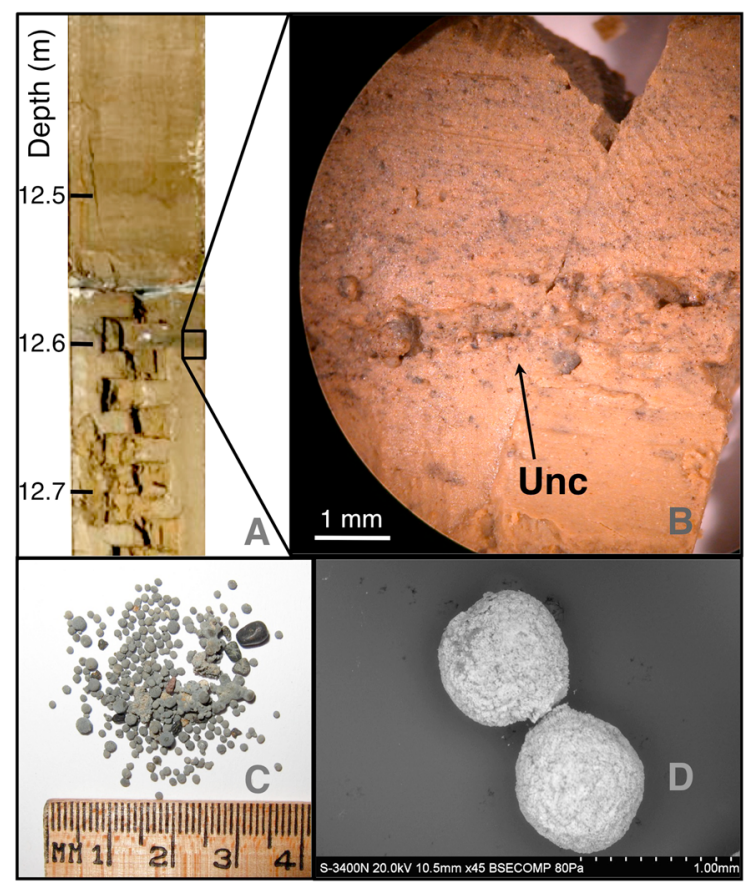

Figure 3. Lithologic evidence supporting the presence of an unconformity in the BB3-I core at $12.6 \mathrm{~m}$ below the ground surface. (a) Prominent color change at $12.6 \mathrm{~m}$ (note core break at $12.57 \mathrm{~m}$ ). Sediments are massive below and laminated above the unconformity. (b) Sediments have relatively uniform grain size and are fine grained below unconformity. The unconformity consists of a coarse sand layer that fines upward into the laminated sediments shown in Figures $3 a$ and $3 c$. Washed coarse grains from the coarse sand layer at the base of the unconformity consist of rounded basalt pebbles and spherical carbonate growths (ooids?). Both are suggestive of shallow water, wavedominated deposition consistent with a transgressive sand above an unconformity. (d) Scanning electron microscope image of spherical carbonate growths. assertion is supported by $M_{\mathrm{rs}} / k$ values of $<<70 \mathrm{kA} / \mathrm{m}$ (Figure 4i) [Snowball and Thompson, 1990], $S$ ratio values of $>$ [0.9] (Figure 4j) [Evans and Heller, 2003], and by XRD and SEM/energy-dispersive $X$-ray analyses of magnetic separates (Figures 6-8).

XRD analyses of magnetic separates from samples ranging in depth from 950 to $1290 \mathrm{~cm}$ are shown in Figure 6 and are from the same depths as the samples corresponding to the hysteresis curves shown in Figure 5. The XRD peaks correspond to the characteristic peaks for magnetite, titanomagnetite, and other magnetic spinels; peaks corresponding to greigite are not present. Although small amounts of maghemite, hematite, and ilmenite were identified using reflected-light microscopy, these minerals are not evident in the XRD patterns, indicating that their abundance is minor. The $X$-ray diffractograms also indicate the presence of plagioclase feldspar, which is confirmed by SEM and EDS analyses (Figure 7). It is possible that the feldspars contain small magnetite inclusions [e.g., Feinberg et al., 2005], which accounts for their inclusion in the magnetic-mineral separates.

Results of 656 SEM-EDS analyses of magnetic mineral grains are shown in Figure 8. The overwhelming majority of the grains are titanomagnetite with $\mathrm{Fe}: \mathrm{Ti}$ atomic ratios between 7.5:2.5 and 8.5:1.5, but the magnetic minerals have variable compositions ranging between those for magnetite and ulvospinel. Most grains contain small amounts of $\mathrm{Cr}, \mathrm{Mg}$, and Al. Trace amounts of Mn, V, and Si are also common.

The uniformity of the concentration and grain size of magnetic minerals over the studied interval, especially within the excursion zone, is demonstrated by plots of $k$, ARM, IRM, and their ratios (Figure 4), which suggests that the magnetic carriers are suitable for relative paleointensity (RPI) normalization [King et al., 1983; Tauxe, 1993]. In support of this contention, all three intensity normalization estimates produce consistent RPI estimates versus depth (Figure 9).

Prominent discontinuities in declination, RPI, and magnetic concentration parameters at $12.6 \mathrm{~m}$ support the presence of the unconformity inferred from sedimentologal observations (Figures 4 and 9). Thus, the hypothesis of a stratigraphic break at this depth is supported by magnetic results, sedimentology (Figure 3), and ${ }^{14} \mathrm{C}$ dates (Figure 2).

\subsection{The Mono Lake Excursion}

\subsubsection{Regional Reproducibility of Vector Components}

The classic features of the MLE (Figure 9) from the sediments of the Wilson Creek Formation around the shore of Mono Lake, as demonstrated by several previous studies [Denham and Cox, 1971; Liddicoat and Coe, 1979; Lund et al., 1988; Liddicoat, 1992], appear in our new record from the Summer Lake BB3-I core in a subset of 78 samples between 11.0 and $9.6 \mathrm{~m}$. From bottom to top, the MLE is evident through the following features: (1) an initial westward declination swing between 11.0 and $10.7 \mathrm{~m},(2)$ an RPI minimum at 10.8-10.7 m, (3) an inclination minimum at 10.6-10.5 m, (4) an inclination maximum centered at $10.15 \mathrm{~m}$, and finally, (5) an eastward declination swing that peaks shortly above the inclination maximum. Data from the most detailed 


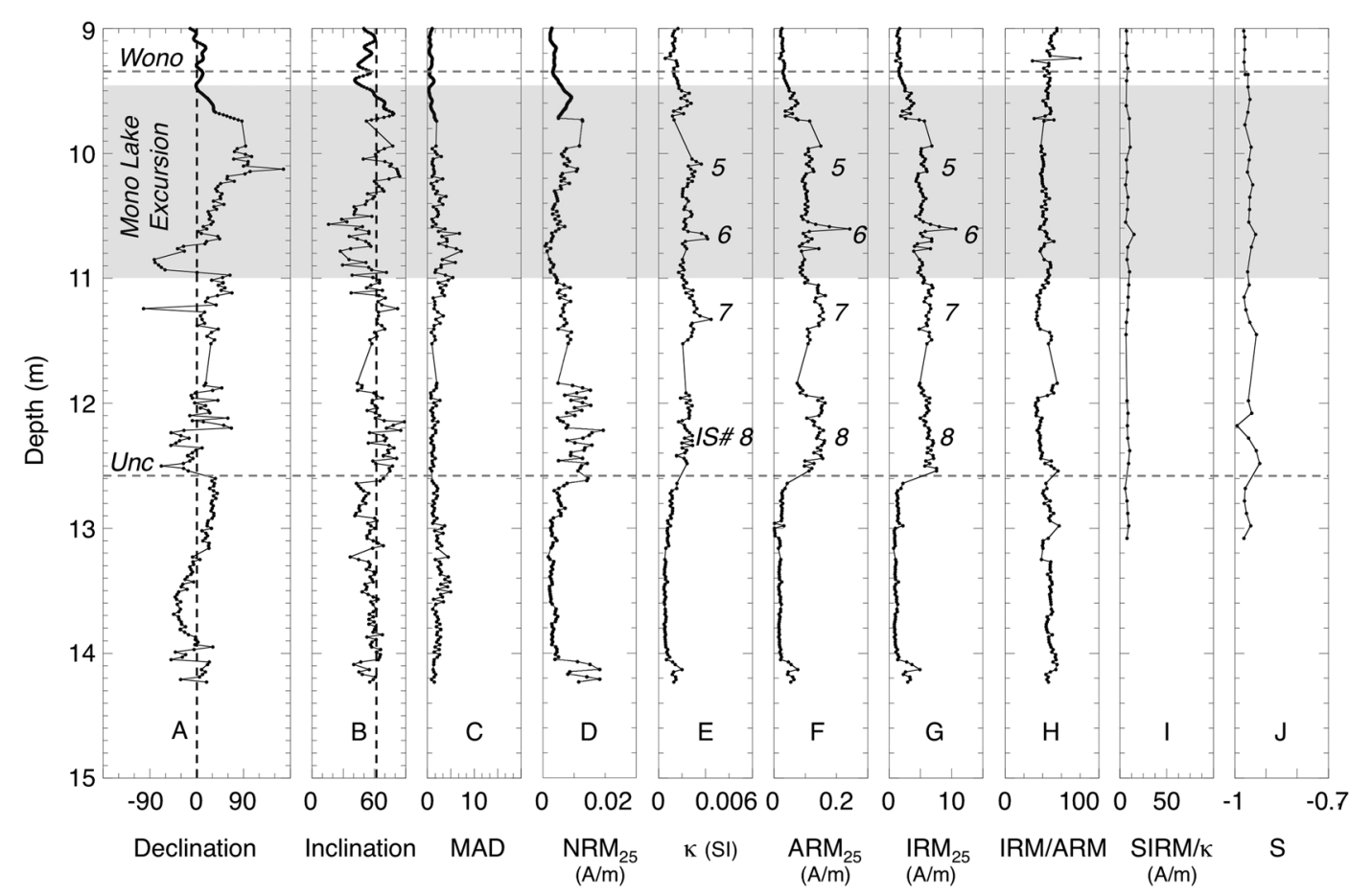

Figure 4. (a) Declination, (b) inclination, (c) maximum angular deviation (MAD), (d) natural remanent magnetization after alternating field demagnetization at $25 \mathrm{mT}$, (e) volume-normalized magnetic susceptibility, (f) anysteretic remanent magnetization, (g) isothermal remanent magnetization, (h) IRM/ARM to demonstrate relatively uniformity of magnetic mineral grain size, (i) ratio of saturation isothermal remanent magnetization over susceptibility, (j) $S$ ratio (ratio of backfield IRM $\mathrm{I}_{100 \mathrm{mT}}$ to saturation isothermal remanent magnetization). The uppermost $0.75 \mathrm{~m}$ of Figures $4 \mathrm{a}-4 \mathrm{~d}$ are from $\mathrm{u}$-channel measurements taken at every centimeter. The rest of the data correspond to discrete samples. Dansgaard-Oeschger interstadial numbers 5-8 are assigned to magnetic concentration-dependent parameters in Figures 4e-4g [after Zic et al., 2002].

Wilson Creek/Mono Lake record [Liddicoat, 1992] and from the PLC08-1 core from Pyramid Lake, Nevada [Benson et al., 2008], indicate that the major features of this excursion are reproducible between different sites in the Great Basin of western North America as expected due to the close proximity of the Great Basin localities relative to the geographic scale required for detectable differences in magnetic fields due to outer core sources [Harrison and Ramirez, 1975]. The stratigraphic correlation of tephra layers that are common between the records (Table 1) [Davis, 1985; Benson et al., 2013] illustrates the coeval nature of the records (Figure 10). All records agree well with the one exception of the Wilson Creek RPI record; it fails to reproduce the increase in intensity that is evident in the other two records in the uppermost part of the excursion.

\subsubsection{Duration of the MLE}

Based on its RPI anomaly in the North Atlantic palaeointensity stack since 75 ka stack [e.g., Laj and Channell, 2007], the duration of the MLE has been estimated to be of the order of a millennium. A longer duration of $\sim 3 \mathrm{kyr}$, however, is suggested if, in addition to the RPI signature of the excursion, one considers all inclination and declination anomalies from the westward declination swing at the excursion onset through the eastward swing at the end of the excursion. According to Zic et al. [2002], the IRM record of the adjacent BB1 core correlates with the Greenland Ice Sheet Project 2 and Greenland Ice Core Project climate stratigraphies and, based on this correlation, the low inclination and RPI anomalies lie within interstadial Dansgaard/Oeschger events IS\#7 and IS\#6, which is consistent with the cosmogenic isotopebased placement of the MLE by Wagner et al. [2000]. Extending this correlation over the entire excursion, the MLE started immediately after the termination of IS\#7 and continued until the end of IS\#5 (Figures 4 and 9). Using the Greenland Ice Core Chronology 2005 for Greenland ice cores [Andersen et al., 2006; Svensson et al., 2005, 2008], this represents a $\sim 3 \mathrm{kyr}$ time interval from 35 to $32 \mathrm{ka}$. This age range is somewhat younger than that inferred from the radiocarbon dates in Figure 2a which suggests that the lake reservoir effect is closer to the maximum estimate of $3 \mathrm{kyr}$ rather than the conservative 500 years used for the corrected values shown in Figure 2a. 

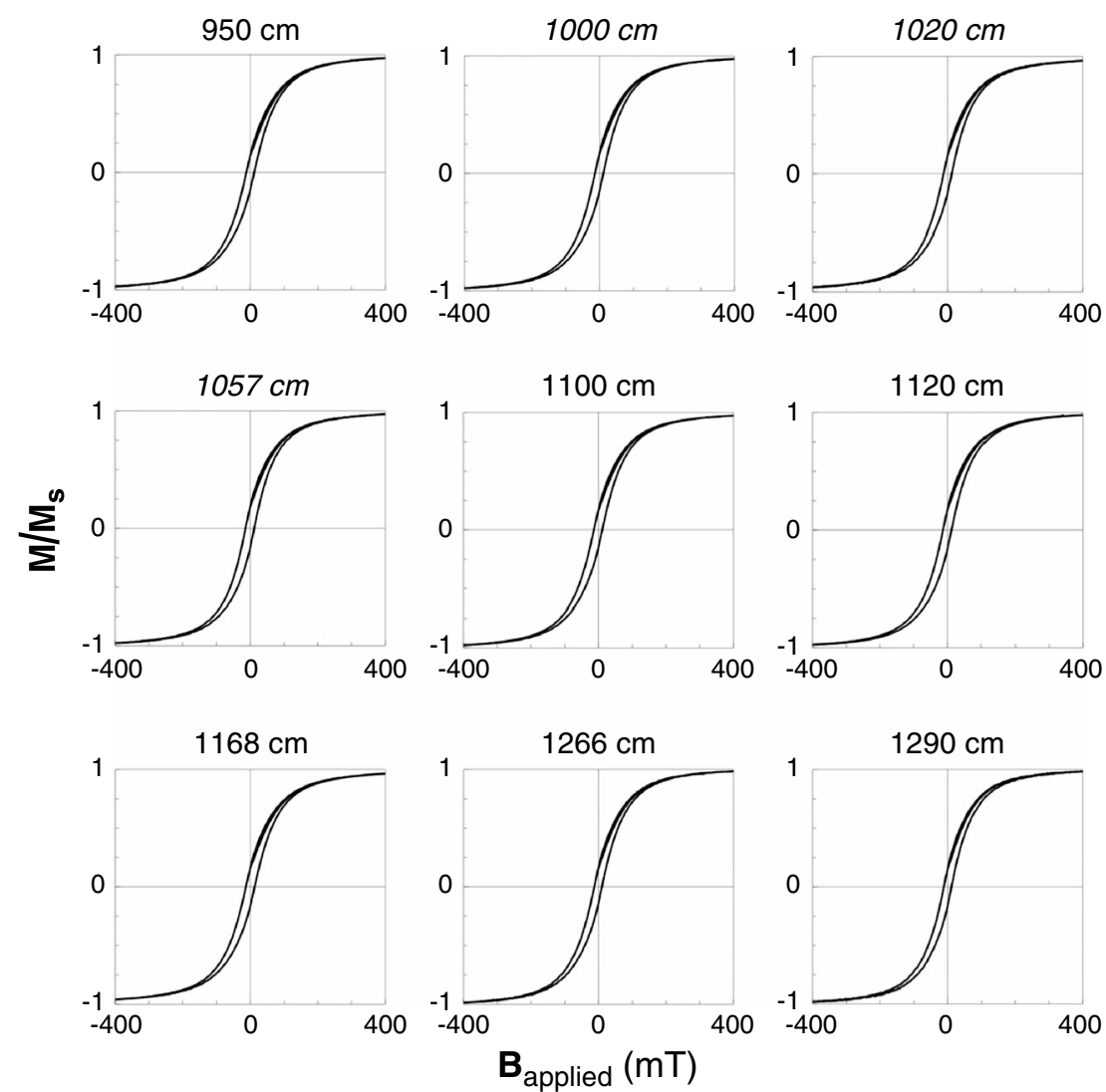

Figure 5. Hysteresis loops for representative samples throughout the studied core interval demonstrating the uniformity of magnetic minerals throughout. Depths are indicated for every sample in centimeter belowground surface. Italicized depths correspond to samples from the excursion zone. The tightness of the loops is consistent with the presence of magnetic psuedosingle domain grains while loop closure below $\pm 200 \mathrm{mT}$ is consistent with magnetite-like mineralogy [Tauxe, 2009].

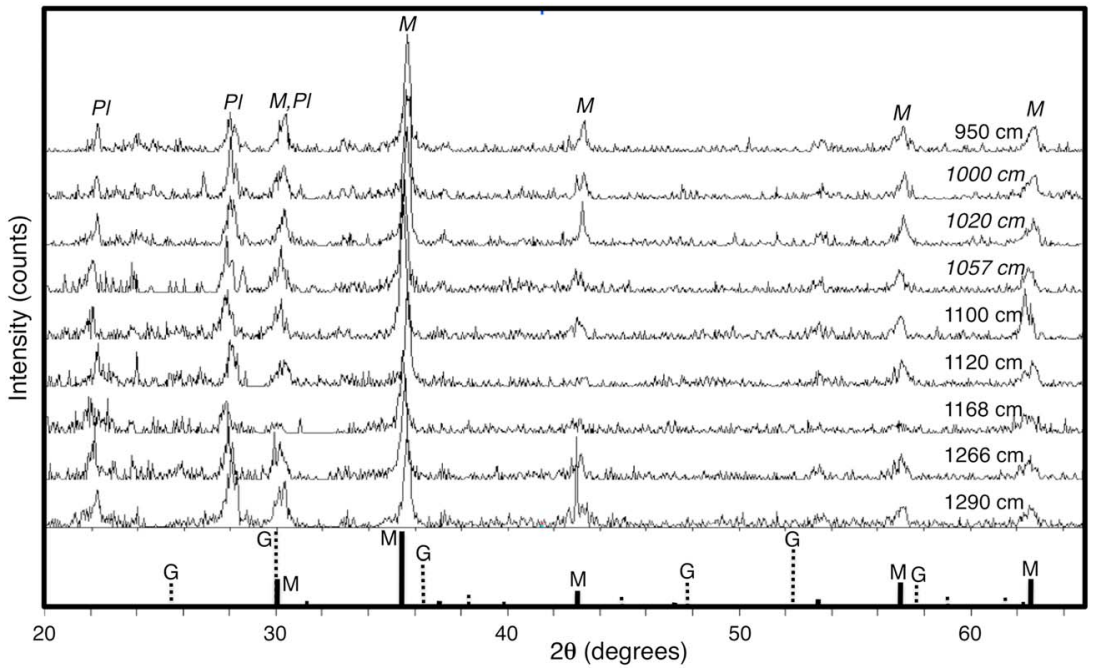

Figure 6. XRD analyses for magnetic separates from the same intervals as the samples used in the hysteresis measurements shown in Figure 5. The observed $(M)$ peak positions correspond with those expected for magnetite, titanomagnetite, and other magnetic spinels; peaks corresponding to greigite $(\mathrm{G})$ are not present. Plagioclase (PI) was also present in the magnetic separates. 


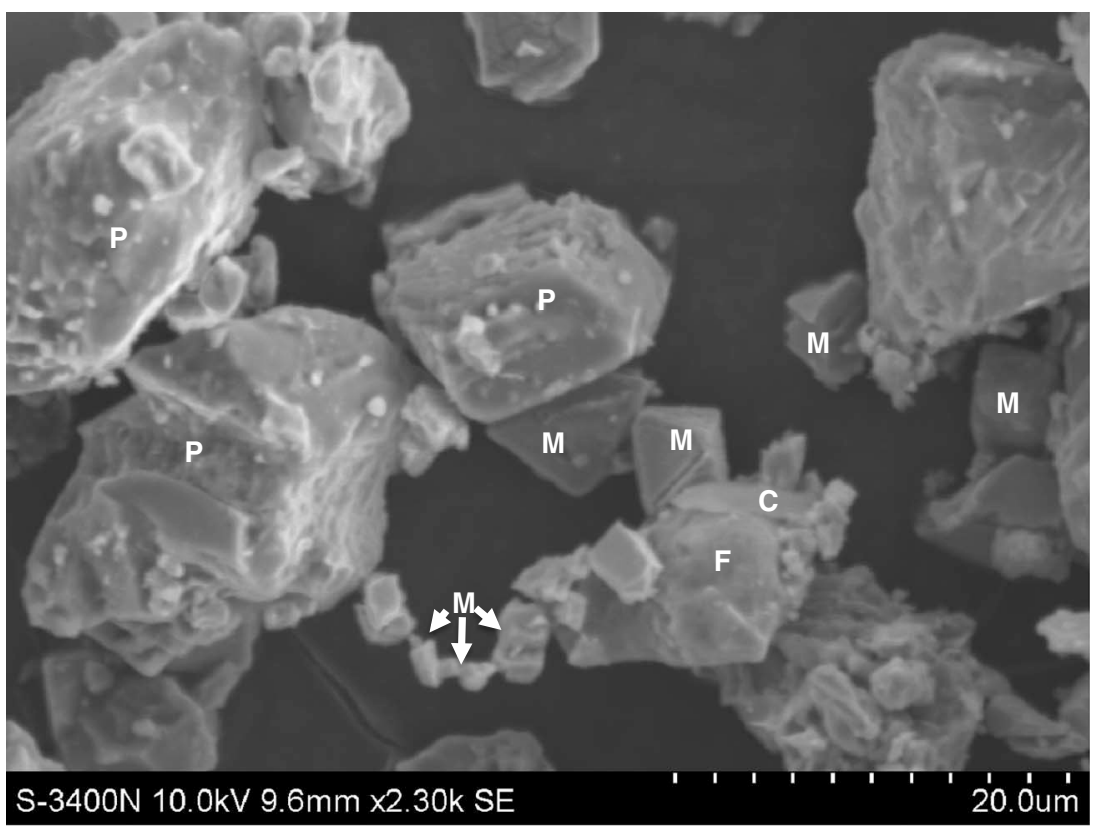

Figure 7. Secondary electron image of grains in the magnetic separates. In addition to detrital magnetite grains (M), detrital plagioclase (PI), chlorite (C), and an unidentified ferromagnesian silicate $(\mathrm{F})$ were extracted. Mineralogy of grains was based on elemental abundances identified by energy-dispersive X-ray analyses (EDS) and by morphology. Image shown is from a depth of $1100 \mathrm{~cm}$.

\subsubsection{Similar MLE VGPs Paths for the Summer Lake and Irminger Basin Records}

The VGPs associated with the directional data in the excursion zone are plotted in Figure 11. Also plotted here, for the first time, are the MLE VGPs from discrete samples associated with the youngest (34-32 ka) of three excursions reported from the ODP-919 record [Channell, 2006]. The VGP paths of the BB3-I and ODP-919 MLE records are remarkably similar. Both sets of VGPs move rapidly between the same three cluster positions after residing in them for time intervals corresponding to at least several samples. In the BB3-I record, the excursion begins with the VGPs moving to a region in the western equatorial Pacific (WPac), then moving to North Atlantic/Europe cluster (NAtl/Euro), and, finally, to a southern North America cluster (SNAm) after which the excursion ends. For the ODP-919 record, the excursion follows the same progression from cluster to cluster with the exception that it starts in the NAtl/Euro cluster, moves on to the SNAm cluster, and lastly to the WPac cluster.
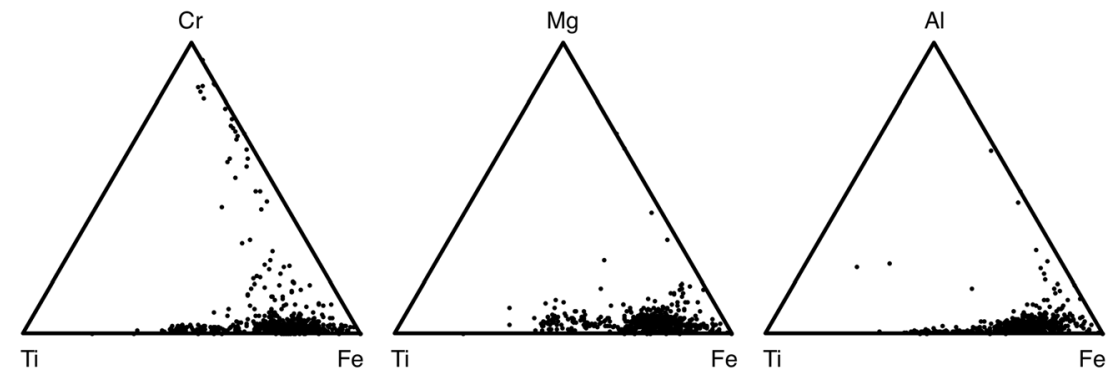

Figure 8. Elemental abundances of 656 SEM-EDS analyses of magnetic mineral grains. The overwhelming majority of the grains are titanomagnetite with Fe:Ti atomic ratios between 7.5:2.5 and 8.5:1.5, but the magnetic minerals have a wide range of compositions ranging between magnetite and ulvospinel. Most grains contain small amounts of $\mathrm{Cr}, \mathrm{Mg}$, and $\mathrm{Al}$ and trace amounts of $\mathrm{Mn}, \mathrm{V}$, and $\mathrm{Si}$. 


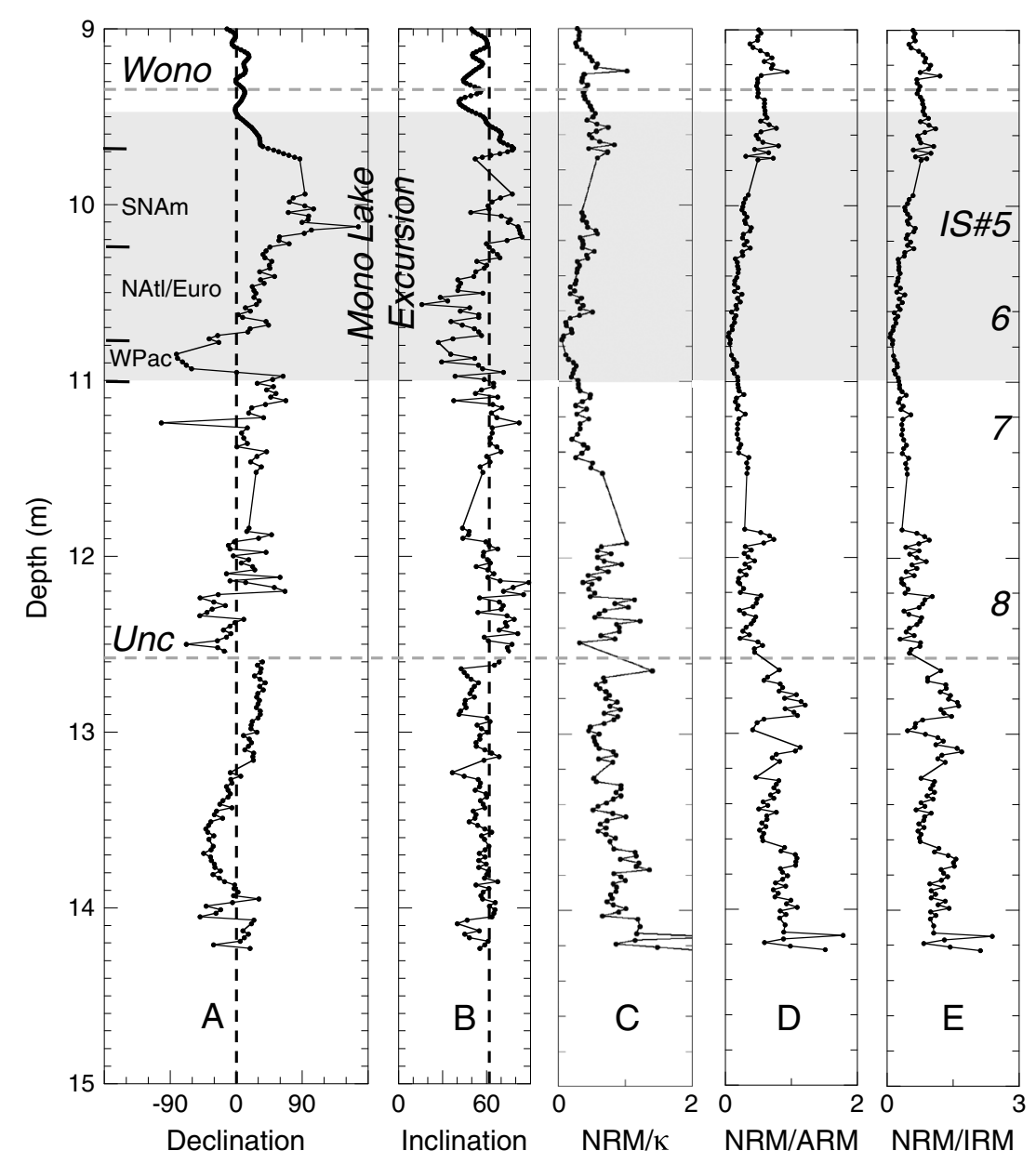

Figure 9. Paleomagnetic vector components for samples from the BB3-I core below and including the Mono Lake Excursion. (a) Declination, (b) inclination, (c) relative paleointensity (RPI) based on natural remanent magnetization/susceptibility, (d) RPI based on natural remanent magnetization/anhysteretic remanent magnetization, and (e) RPI based on natural remanent magnetization/isothermal remanent magnetization. All three normalization techniques yield consistent RPI values. Note that discontinuities in the declination and RPI records at $12.6 \mathrm{~m}$ support the hypothesis that a significant amount of time is missing, associated with the unconformity found at this depth (Figures 2,3). Dansgaard-Oeschger interstadial numbers 5-8 are positioned consistent with the depths of the associated magnetic concentration-dependent parameters in Figures $4 \mathrm{e}-4 \mathrm{~g}$.

\section{Discussion}

\subsection{The Magnetic Field During the Mono Lake Excursion}

\subsubsection{Disappearing Magnetic Field Except for Oscillating Flux Centers}

Based on the pattern associated with the VGP paths in Figure 11, it is apparent that, at least for the large geographic region containing the Summer Lake and Irminger Basin localities, field behavior during the 35-32 ka MLE is dominated by recurrent movement of VGPs to the same clusters. Coeval VGP positions from previously published lava flow records are sparse but essentially occupy the same clusters (Figure 12a), suggesting that these cluster positions dominate MLE field behavior as observed from localities extending into the eastern Atlantic Ocean [Kissel et al., 2011], Europe [Plenier et al., 2007, and references therein], and even New Zealand [Cassata et al., 2008, 2010].

The above observations suggest the following. During the excursion, the field is dominated by centers of flux corresponding to the three cluster locations indicated in Figure 11. These flux centers exchanged dominance as they oscillated in strength during the excursion. As a result, VGPs from far removed localities were drawn to the dominant flux center when associated field lines were radially downward. The oscillation frequency of the flux centers was high enough that dominance exchanged 4 times during the 1-3 kyr long excursion (i.e., one oscillation every 250 to 750 years). 


\section{Summer Lake BB3-I Core}

\author{
Pyramid Lake \\ PLC08-1 Core
}

\section{Mono Lake Mill Creek Outcrop}
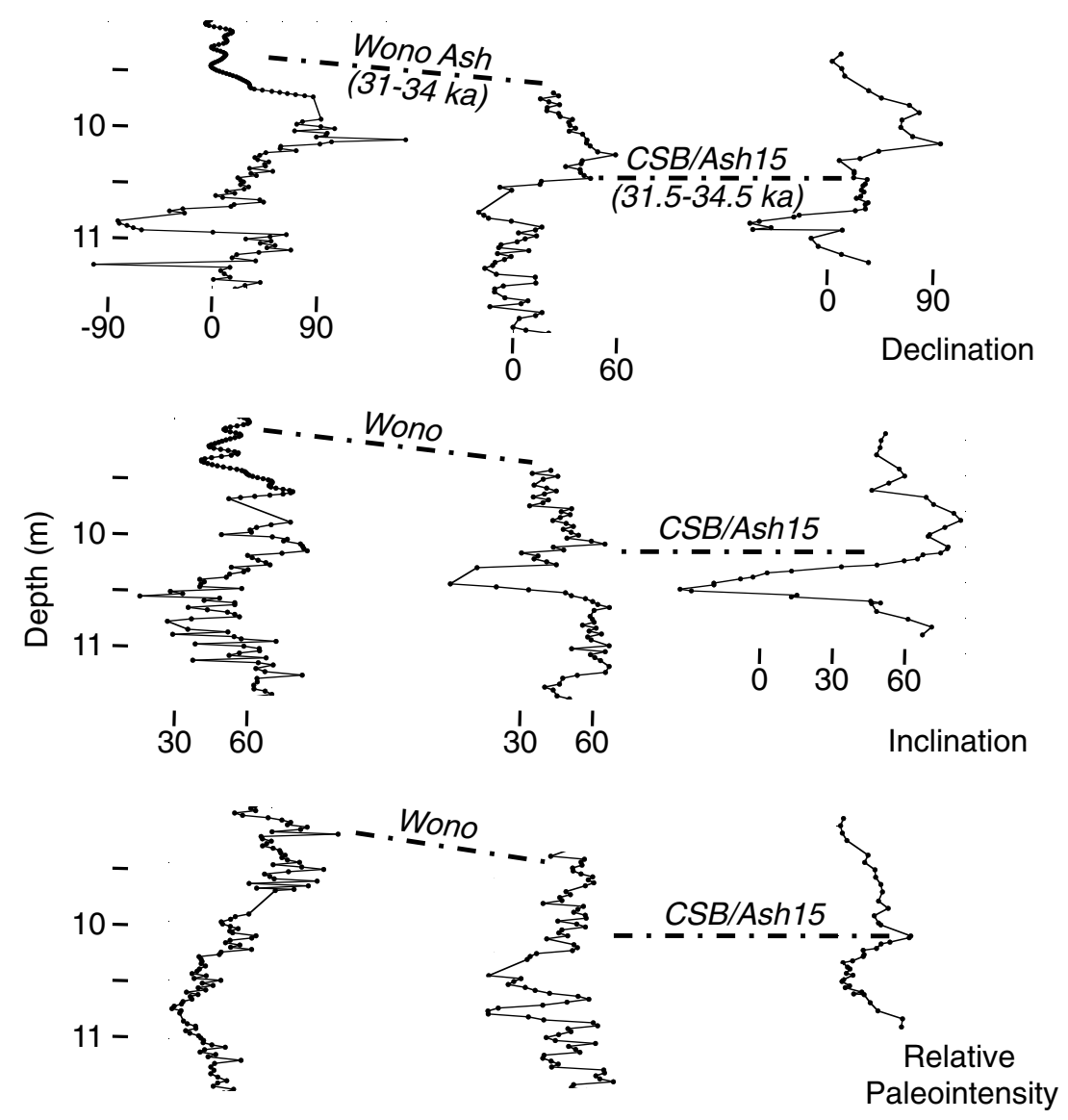

Figure 10. Paleomagnetic vector components throughout the Mono Lake excursion from the BB3-I record at Summer Lake, Oregon, the PLC08-1 core at Pyramid Lake, Nevada [Benson et al., 2008], and the Mill Creek outcrop of the Wilson Creek sediments at the Mono Lake Basin, California [Liddicoat, 1992]. Relative ages of these sequences are based on geochemically correlated volcanic ashes [Davis, 1985; Benson et al., 2003a, 2008, 2013; Kuehn and Negrini, 2010], the Wono and Wilson Creek Ash 15 (aka Carson Sink Bed), which established that all three sequences are recording the same excursion. The depth scale for the BB3-I core is the same as that in Figure 9. Scale bars show relative depths for Pyramid Lake and Mono Lake records.

This model is consistent with the results of previous studies on nonaxial dipole field behavior associated with flux centers that are dominantly fixed with respect to location, magnitude, and oscillation frequency. First, dynamo studies have demonstrated that recurrent flux centers at more or less fixed locations can exist as a result of the effects of lower mantle inhomogeneities on the dynamo process [Bloxham, 2002; Olson and Christensen, 2002; Gubbins et al., 2007; Aubert et al., 2008]. Second, a takeover by a long-lived nonaxial dipole field in the absence of the dipole field during polarity transitions is also consistent with paleomagnetic results. For example, Hoffman and Singer [2008] reported VGPs of Pleistocene-aged transitional directions from lavas in Germany and Tahiti. In each case, the transitional VGPs plot in the same locations as those associated with historic nonaxial dipole fields for the respective sites [Hoffman and Singer, 2008]. Perhaps the most straightforward support for the persistence of flux centers suggested by the clusters in Figure 11 is provided by Korte et al. [2009], who developed models of nonaxial dipole radial flux (NAD $\left.B_{r}\right)$ representing the most recent 3 ka using input from global archeomagnetic and sedimentary records (their Figure 13c). Most of the models, including their preferred model, CALS3k.3, contain concentrations of downward directed radial flux in similar locations as the WPac, SNAm, and NAtI/Euro clusters (see blue, dashed contours in Figure 11). The strength of these radial flux centers approach $10 \mu \mathrm{T}$ which is a significant fraction of the maximum strength of the current dipole field. Thus, if any of these flux centers was dominant at certain times during an 


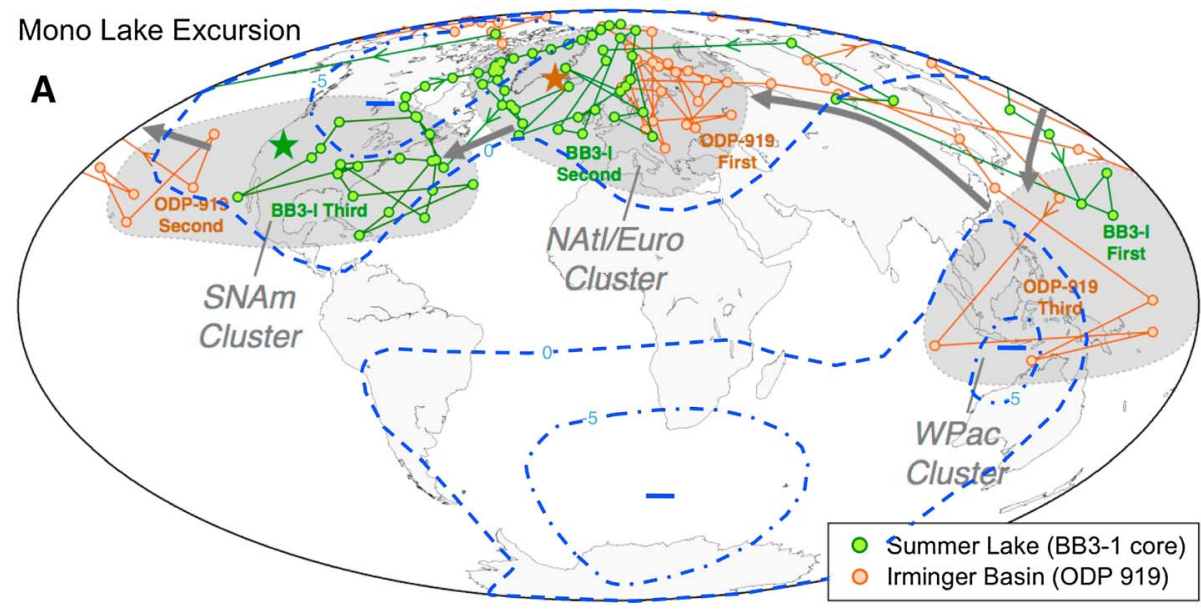

B
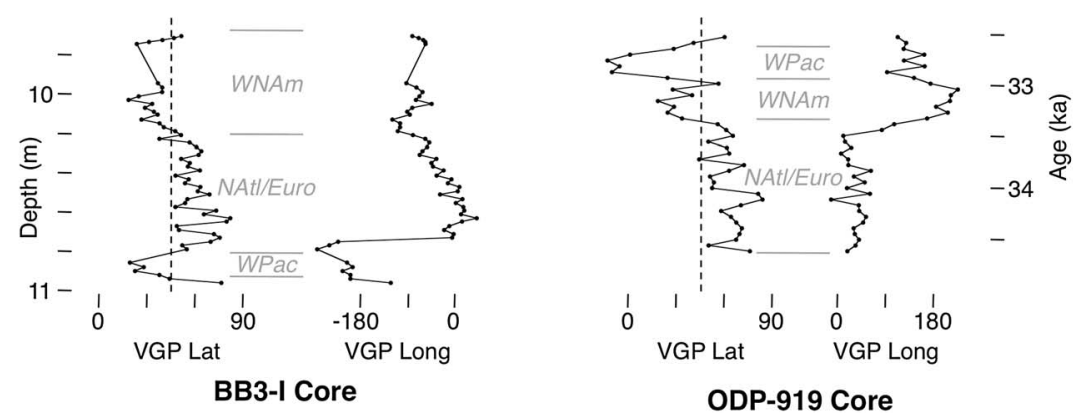

Figure 11. (a) Virtual geomagnetic pole (VGP) paths of the Mono Lake excursion associated with BB3-I (green) and ODP919 (orange) discrete sample records from Summer Lake, OR, USA, and Irminger Basin, North Atlantic Ocean, respectively. Star symbols indicate site localities. Arrows indicate the progression of the path sequences through three clusters exhibited by both records. The clusters are defined by grey areas and labeled west equatorial Pacific (WPac), North Atlantic/ Europe (NAt//Euro), and southern North America (SNAm). The BB3-I sequence starts in the WPac cluster; the ODP-919 sequence starts in the NAtl/Euro cluster. Regions of downward radial flux of the nonaxial dipole associated with model CAL3k.3 of Korte et al. [2009] are outlined with blue dashed lines. (b) VGP latitude and longitude versus depth for the BB3-I record and versus age for the ODP-919 record. Depth intervals corresponding to VGP clusters are indicated in italics. Dashed lines in the VGP latitude plots indicate the arbitrary $45^{\circ}$ boundary commonly used to distinguish excursional from nonexcursional directions.

excursion when the axial dipole field was very weak, then it could dominate the field globally and thus result in the VGP paths indicated in Figure 11.

Oscillation frequencies of the dominant inferred flux patches would be required to allow four exchanges during the excursion which likely lasted 1-3 kyr. Such an oscillation frequency is consistent with the findings of Amit et al. [2011], who suggested a 300 year average lifetime of flux patches based on a comparison of Holocene and modern magnetic field reconstructions designed to investigate the time dependence of flux patches. Using similar data sets, but concentrating on core surface flows not restricted to flux patches attributed to the nonaxial dipole field, Wardinski and Korte [2008] estimated core surface flow periodicities between $\sim 500$ and 1000 years.

\subsubsection{Geographical Variation in the Timing of the Excursion}

Exchange between dominant flux centers during the MLE followed a consistent sequence from WPac to NAtI/ Euro to SNAm to WPac, but that sequence started at a different center for each record locality (Figure 11). This observation suggests that the intensity of the main field (i.e., all of the field not attributed to the flux centers) died out in a time-transgressive manner between the Summer Lake and Irminger Basin localities. That is, it appears that the excursion commenced (i.e., the main field intensity dropped to a negligible value) first at the Summer Lake locality when the WPac center was dominant. Then the onset of the excursion migrated to include the Irminger Basin locality. At this time both localities were in the excursion and both sets of VGPs 

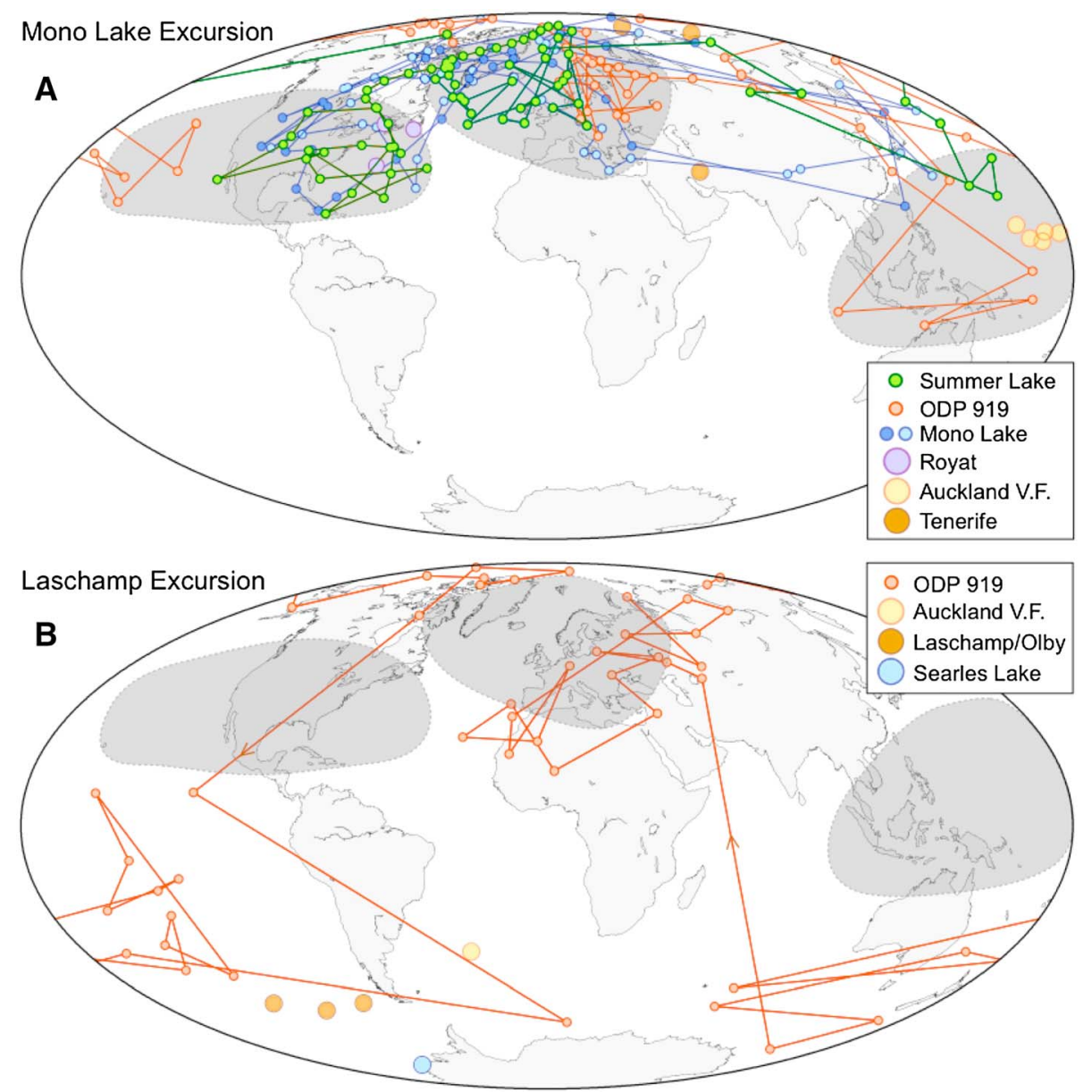

Figure 12. VGPs and VGP paths associated for the (a) Mono Lake [Liddicoat, 1992; Plenier et al., 2007; Cassata et al., 2008, 2010; Kissel et al., 2011] and (b) Laschamp [Guillou et al., 2004; Cassata et al., 2008; Knott et al., 2010] excursions. The ODP-919 study [Channell, 2006] also included a discretely sampled record of the Laschamp event shown in orange. The composite paths for the two excursions are clearly different. For example, only the LE contains fully reversed-polarity VGPs. Several additional highresolution sedimentary records of the Laschamp excursion not plotted here support this conclusion, as suggested in earlier studies [Lund et al., 2005; Laj and Channell, 2007; Channell et al., 2012; Nowaczyk et al., 2012]. The path associated with the excursion recorded in the Wilson Creek sediments from Mono Lake clearly corresponds to the Mono Lake excursion.

occupied the NAtl/Euro cluster, which had become dominant. VGPs for both localities then migrated to the SNAm cluster as this flux center oscillated into dominance. Thereafter, the excursion ended (i.e., the main field intensity returned to dominance) starting at the Summer Lake locality as the BB3-I VGPs returned to the high latitudes typical of normal secular variation while those at ODP-919 which were still dominated by the final phase of the excursion migrated to the WPac cluster as this flux center strengthened. Finally, the excursion also terminated at the Irminger Basin locality. We note that the above hypothesis, while explaining the observations well, will require improvements in age control methods to achieve the submillenial-scale precision necessary for definitive testing.

\subsection{The MLE at Mono Lake is Not the Laschamp Excursion}

Based on alternative chronologies, several studies suggested that the excursion recorded in the sediments around Mono Lake is not a distinct excursion but instead is a record of the LE [Kent et al., 2002; Zimmerman et al., 2006; Tauxe, 2009; Cox et al., 2012; Vazquez and Lidzbarski, 2012]. We argue, on the basis of distinct magnetic field behavior associated with MLE records throughout the world and consistent ${ }^{14} \mathrm{C}$ ages of 34-32 ka across the three Great Basin MLE localities, one of which also possesses a record of a lower excursion at $\sim 40 \mathrm{ka}$ (i.e., the LE), that the original interpretation of the MLE and LE as different excursions is better supported by the existing data [Denham and Cox, 1971; Benson et al., 2003a, 2008; Cassata et al., 2010]. 
First, the field behavior associated with the MLE is clearly distinct from that of the LE. Whereas records of the LE include VGPs that reached high southern latitudes, VGPs associated with the MLE are restricted to latitudes no farther south of the equator than $\sim 10^{\circ}$ (Figure 12). VGPs of the MLE from Great Basin and Irminger Basin sediments are also consistent with previously published records of the MLE from globally distributed localities (Figure 12a), including several containing both the MLE and LE [Laj and Channell, 2007, and references therein; Nowaczyk et al., 2012]. Furthermore, a model of field behavior during the LE, which accurately reproduces six globally distributed, high-fidelity records of the event, fails to reproduce the declination and inclination changes observed during the MLE [Leonhardt et al., 2009].

If our interpretation is correct, it seems that unresolved ambiguities related to protracted crystal residence or xenocrystic contamination may beset (U-Th)/He and U-Th isotope disequilibrium dating of Ash 15 at Mono Lake, which bisects the excursion. One possible explanation for the $40.8 \pm 1.9$ ka U-Th isotope disequilibrium age obtained from euhedral allanite and zircon crystals that appear to have been in equilibrium with the melt [Vazquez and Lidzbarski, 2012] is that crystallization occurred several kiloannum prior to eruption, a common phenomenon in silicic systems. Likewise, one possible interpretation of (U-Th)/He ages ( $34.9 \pm 1.1$ to $43.5 \pm 1.3 \mathrm{ka}, 38.7 \pm 1.2 \mathrm{ka}$ (mean $\pm 2 \mathrm{SE}$ ), and mean square weighted deviation $=3.8$ ) [Cox et al., 2012] from anhedral allanite crystals that yielded significantly older U-Th isotope disequilibrium crystallization ages $(66.0 \pm 3.3 \mathrm{ka})$ is that they reflect incompletely degassed xenocrysts. These crystals may have been incorporated from older volcanic centers or underlying sediments immediately prior to or during the eruption, as was proposed to explain the ubiquitous presence of xenocrystic sanidine and biotite crystals in which the K-Ar system was not reset by the eruption [Cassata et al., 2010]. Given typical differences in He and Ar diffusion kinetics [e.g., Farley, 2002; Cassata and Renne, 2013], the (U-Th)/He system was likely more susceptible to resetting, which may explain why the youngest apparent ages reported by Cox et al. [2012] approach the $\sim 32-34$ ka radiocarbon constraint on the age of deposition.

If, however, our interpretation is incorrect and the excursion at Mono Lake has an age of $\sim 41 \mathrm{ka}$, then either (1) it does not correlate with the excursion identified at Summer Lake, Pyramid Lake, and Carson Sink, despite its remarkable paleomagnetic similarity and correlated tephra layers or (2) it does correlate with these records, but the $\sim 32-34$ ka radiocarbon age obtained at all three localities is incorrect, presumably due to a similar level of modern carbon contamination despite the fact that the material was sampled from core at two different core laboratories (BB3 and PLC-08 records) and from outcrop (Mono Lake record). This would further require similar levels of contamination at three different radiocarbon facilities. Regardless, both scenarios imply that apparent differences in paleomagnetic behavior between global records of the LE and the MLE are not significant and that the failure of the model of Leonhardt et al. [2009] on field behavior of the LE to reproduce the field changes associated with the excursion at Mono Lake is not significant.

On balance, to us the evidence is clear. The LE and MLE are distinct events defined by much different geomagnetic behavior. Further, the age control evidence adequately asserts that they are separated in time by several thousands of years. Because much of unambiguous paleomagnetic directional, RPI, and chronological evidence comes from or is closely tied to the original Mono Lake localities (e.g., Figures 10 and 12), we disagree with the suggestion of Laj et al. [2014] that the Mono Lake excursion should be renamed the Auckland excursion.

The distinctness of the field behavior associated with the two excursions also has paleoclimatological implications. The alternative chronology associated with the one excursion hypothesis predicts dramatically slower sedimentation rates for western Great Basin lakes and the corresponding dominance of low amplitude, smoothly varying, obliquity-driven insolation changes as a driving influence on lake level [Zimmerman et al., 2006]. Furthermore, a dramatic nonlinear response of Mono Lake levels to obliquity would be required to explain the square-wave nature of the $\mathrm{CaCO}_{3}$ lake-level proxy and the inconsistent relationship between the abrupt changes implied by the $\mathrm{CaCO}_{3}$ proxy and the associated phase of the obliquity signal [Zimmerman et al., 2006, Figure 8]. In contrast, the chronologies associated with distinct excursions predict faster sedimentation rates, more discontinuous deposition, and abrupt square-wavelike changes in proxy-based lake levels in response to high-amplitude, hemispheric, and millennial-scale climate change associated with Heinrich events and Dansgaard-Oeschger oscillations [e.g., Benson et al., 1998, 2003b, 2013; Zic et al., 2002]. The latter scenario also predicts widespread lowstands and unconformities in the western Great Basin in association with stadial phases of millennial-scale oscillations, including lake 
dessications and corresponding unconformities during Heinrich event 4 [Svensson et al., 2005, 2008]. As a result, the $\sim 41$ ka LE would have occurred at the beginning of very low lakes or dry lake beds in the western Great Basin and thus likely would not have been recorded unless the depocenters of extant lakes were sampled. Notably, unconformities of this age are found in the Summer Lake sediments (e.g., Figures 2-4 and 9) and are represented by the basal gravels in the Wilson Creek Formation [Lajoie, 1968; Liddicoat and Coe, 1979] which explains the fact that the LE is missing from these records. It is also notable that both the LE and MLE are found in the record from Pyramid Lake, Nevada [Benson et al., 2008], which is an exceptionally deep basin lake that still contains abundant water despite significant historic drainage diversion.

\section{Acknowledgments}

All data used herein are available upon request from the first author. This study was funded by NSF grants EAR\#0911351, HRD\#1137774, and EHR\#030332 and by the Chevron USA REVS-UP summer research program. This work benefited from a graduate student fellowship awarded to Dan McCuan at the Institute of Rock Magnetism. R. Reynolds is acknowledged for his guidance regarding reflected-light microscopy of magnetic separates. Tephra analyses were done by F. Foit, Jr., in the Geoanalytical Laboratory of Washington State University, Pullman, WA. We are grateful to K. Danley, R. Rodriquez, and A. Kylasa for assistance with characterization of the $12.6 \mathrm{~m}$ unconformity, to I. Herrera, K. Sevier, C. Soto, G. Thompson, and A. Ying Wang for assistance with SEM EDS analysis of magnetic separates, and to T. Osborn, E. Powers, and K. Eickenhorst for technical assistance at CSUB. M. Harden, S. Pezzopane, and P. Arredondo assisted with coring as did Julie Bryant and other personnel of the Summer Lake Playa Residence for writers, artists, and natural scientists. Supportive reviews by A. Roberts and two anonymous reviewers greatly improved the manuscript.

\section{References}

Abbott, M. B., and T. W. Stafford Jr. (1996), Radiocarbon geochemistry of modern and ancient Arctic lake systems, Baffin Island, Canada, Quat. Res., 45, 300-311.

Allison, I. S. (1982), Geology of Pluvial Lake Chewaucan, Lake County, Oregon, pp. 78, Oregon State Univ. Press, Corvallis, Ore.

Amit, H., M. Korte, J. Aubert, C. Constable, and G. Hulot (2011), The time-dependence of intense archeomagnetic flux patches, J. Geophys. Res. 116, B12106, doi:10.1029/2011JB008538.

Andersen, K. K., et al. (2006), The Greenland Ice Core Chronology 2005, 15-42 ka. Part 1: Constructing the time scale, Quat. Sci. Rev., 25, 3246-3257, doi:10.1016/j.quascirev.2006.08.002.

Aubert, J., H. Amit, G. Hulot, and P. Olson (2008), Thermo-chemical flows couple the Earth's inner core growth to mantle heterogeneity, Nature, 454, 758-761, doi:10.1038/nature07109.

Benson, L. V., J. P. Smoot, M. Kashgarian, A. Sarna-Wojcicki, and J. W. Burdett (1997), Radiocarbon ages and environments of deposition of the Wono and Trego Hot Springs Tephra layers in the Pyramid Lake sub basin, Nevada, Quat. Res., 47, 251-260.

Benson, L. V., S. P. Lund, J. W. Burnett, M. Kashgarian, T. Rose, J. P. Smoot, and M. Schwartz (1998), Correlation of Late-Pleistocene lake-level oscillations in Mono Lake, California, with North Atlantic climate events, Quat. Res., 49, 1-10.

Benson, L., J. Liddicoat, J. Smoot, A. Sarna-Wojcicki, R. Negrini, and S. Lund (2003a), Age of Mono Lake excursion and associated tephra, Quat. Sci. Rev., 22, 135-140.

Benson, L., S. Lund, R. Negrini, B. Linsley, and M. Zic (2003b), Response of North American Great Basin Lakes to Dansgaard-Oeschger oscillations, Quat. Sci. Rev., 22, 2239-2251.

Benson, L., S. Lund, S. Mensing, J. Smoot, J. Liddicoat, R. Negrini, and M. Schwartz (2008), A tale of TWO excursions (Mono Lake and Laschamp) recorded in sediments of Pyramid Lake, Nevada, EOS Trans. AGU, 89, GP21B-0785.

Benson, L., J. Smoot, S. Lund, S. Mensing, F. Foit Jr., and R. Rye (2013), Insights from a synthesis of old and new climate-proxy data from the Pyramid and Winnemucca lake basins for the period 48-11.5 cal ka, Quat. Int., 310, 62-82, doi:10.1016/j.quaint.2012.02.040.

Bloxham, J. (2002), Time-independent and time-dependent behaviour of high-latitude flux bundles at the core-mantle boundary, Geophys. Res. Lett., 29(18), 1854, doi:10.1029/2001GL014543.

Cassata, W. S., and P. R. Renne (2013), Systematic variations of argon diffusion in feldspars and implications for thermochronometry, Geochem. Cosmochim. Acta, 112, 251-287, doi:10.1016/j.gca.2013.02.030.

Cassata, W. S., B. S. Singer, and J. Cassidy (2008), Laschamp and Mono Lake excursions recorded in New Zealand, Earth Planet. Sci. Lett., 268, 76-88, doi:10.1016/j.epsl.2008.01.009.

Cassata, W. S., B. S. Singer, J. C. Liddicoat, and R. S. Coe (2010), Reconciling discrepant chronologies for the geomagnetic excursion in the Mono Basin, California: Insights from new ${ }^{40} \mathrm{Ar} /{ }^{39} \mathrm{Ar}$ dating experiments and a revised paleointensity correlation, Quat. Geochronol., 5, 533-543, doi:10.1016/j.quageo.2010.02.001.

Channell, J. E. T. (2006), Late Brunhes polarity excursions (Mono Lake, Laschamp, Iceland Basin and Pringle Falls) recorded at ODP Site 919 (Irminger Basin), Earth Planet. Sci. Lett., 244, 279-393, doi:10.1016/j.epsl.2006.01.021.

Channell, J. E. T., D. A. Hodell, and J. A. Curtis (2012), ODP Site 1063 (Bermuda Rise) revisited: Oxygen isotopes, excursions and paleointensity in the Brunhes Chron, Geochem. Geophys. Geosyst., 13, 1-27, doi:10.1029/2011GC003897.

Cox, S. E., K. A. Farley, and S. R. Hemming (2012), Insights into the age of the Mono Lake Excursion and magmatic crystal residence time from (U-Th)/He and 230Th dating of volcanic allanite, Earth Planet. Sci. Lett., 319-320, 178-174, doi:10.1016/j.epsl.2011.12.025.

Davis, J. O. (1985), Correlation of late Quaternary tephra layers in a long pluvial sequence near Summer Lake, Oregon, Quat. Res., $23,38-53$. Denham, C. R., and A. Cox (1971), Evidence that the Laschamp polarity event did not occur 13,300-13,400 years ago, Earth Planet. Sci. Lett., 13, $181-190$.

Evans, M. E., and F. Heller (2003), Environmental Magnetism, Academic Press, San Diego, Calif.

Farley, K. A. (2002), (U-Th)/He dating: Techniques, calibrations, and application, in Noble Gases in Geochemistry and Cosmochemistry, Rev. Miner. Geochem., 47, 819-844, doi:10.2138/rmg.2002.47.18.

Feinberg, J. M., G. R. Scott, P. R. Renne, and H.-R. Wenk (2005), Exsolved magnetite inclusions in silicates: Features determining their remanence behavior, Geology, 33, 513-516, doi:10.1130/G21290.1.

Gubbins, D. (1999), The distinction between geomagnetic excursions and reversals, Geophys. J. Int., 137, F1-F3.

Gubbins, D., A. P. Willis, and B. Sreenivasan (2007), Correlation of Earth's magnetic field with lower mantle thermal and seismic structure, Phys. Earth. Planet. Int., 162, 256-260, doi:10.1016/j.pepi.2007.04.014.

Guillou, H., B. S. Singer, C. Laj, C. Kissel, S. Scaillet, and B. R. Jicha (2004), On the age of the Laschamp geomagnetic excursion, Earth Planet. Sci. Lett., 227, 331-343, doi:10.1016/j.epsl.2004.09.018.

Harrison, C. G. A., and E. Ramirez (1975), Areal coverage of spurious reversals of the Earth's magnetic field, J. Geomag. Geoelect., 27, 139-151. Hoffman, K. A., and B. S. Singer (2008), Magnetic source separation in Earth's outer core, Science, 321, 1800, doi:10.1126/science.1159777.

Horton, R. A., Jr., and J. W. Geissman (1990), Geochemistry of the Leadville Formation (Mississippian) and implications for dolomitization, Econ. Geol. Monogr., 7, 66-85.

Horton, R. A., Jr., J. W. Geissman, and R. T. Tschauder (1984), Paleomagnetism and rock magnetism of the Mississippian Leadville (carbonate) Formation and its implications for the age of sub-regional dolomitization, Geophys. Res. Lett., 11, 649-652.

Kent, D. V., S. R. Hemming, and B. D. Turrin (2002), Laschamp Excursion at Mono Lake?, Earth Planet. Sci. Lett., 197, 151-164, doi:10.1016/ S0012-821X(02)00474-0. 
King, J. W., S. K. Banerjee, and J. Marvin (1983), A new rock-magnetic approach to selecting sediments for geomagnetic paleointensity studies: Application to paleointensity for the last 4000 years, J. Geophys. Res., 88, 5911-5921, doi:10.1029/JB088iB07p05911.

Kirschvink, J. L. (1980), The least-squares line and plane and the analysis of palaeomagnetic data, Geophys. J. Int., 62, 699-718, doi:10.1111/ j.1365-246x.1980.tb02601.x.

Kissel, C., H. Guillou, C. Laj, J. C. Carracedo, S. Nomade, F. Perez-Torrado, and C. Wandres (2011), The Mono Lake excursion recorded in phonolitic lavas from Tenerife (Canary Islands): Paleomagnetic analyses and coupled K/Ar and Ar/Ar dating, Phys. Earth Planet. Int., 187, 232-244, doi:10.1016/j.pepi.2011.04.014.

Knott, J. R., J. C. Liddicoat, and R. S. Coe (2010), Paleomagnetic and radiocarbon record of the Searles Lake Formation at Poison Canyon, San Bernardino County, CA, Geol. Soc. Am. Abstr Prog., 42, 76.

Korte, M., F. Donadini, and C. G. Constable (2009), Geomagnetic field for 0-3 ka: 2. A new series of time-varying global models, Geochem. Geophys. Geosyst., 10, Q06008, doi:10.1029/2008GC002297.

Kuehn, S. C., and R. M. Negrini (2010), A 250 k.y. record of Cascade arc pyroclastic volcanism from late Pleistocene lacustrine sediments near Summer Lake, Oregon, USA, Geosphere, 6, 1-33, doi:10.1130/GES00515.1.

Laj, C., and J. E. T. Channell (2007), Geomagnetic excursions, in Treatise on Geophysics, Geomagnetism, vol. 5, edited by G. Schubert et al., pp. 373-416, Elsevier, B.V, Amsterdam.

Laj, C., H. Guillou, and C. Kissel (2014), Dynamics of the Earth's magnetic field in the 10-75 kyr period comprising the Laschamp and Mono Lake excursions: New results from the French Chaîne des Pus in a global perspective, Earth Planet. Sci. Lett., 387, 184-197, doi:10.1016/j. epsl.2013.11.031.

Lajoie, K. R. (1968), Quaternary stratigraphy and geologic history of Mono Basin, eastern California, PhD thesis, Univ. of California-Berkeley, Berkeley, Calif.

Leonhardt, R., K. Fabian, M. Winklhofer, A. Ferk, C. Laj, and C. Kissel (2009), Geomagnetic field evolution during the Laschamp excursion, Earth Planet. Sci. Lett., 278, 87-95, doi:10.1016/j.epsl.2008.11.028.

Liddicoat, J. C. (1992), Mono Lake excursion in Mono Basin, California, and at Carson Sink and Pyramid Lake, Nevada, J. Geophys. J. Int., 108, 442-452.

Liddicoat, J. C., and R. S. Coe (1979), Mono Lake geomagnetic excursion, J. Geophys. Res., 84, 261-271.

Lund, S. P., J. Liddicoat, K. Lajoie, T. Henyey, and S. Robinson (1988), Paleomagnetic evidence for the long-term (104 year) memory and periodic behavior in the Earth's core dynamo process, Geophys. Res. Lett., 15, 1101-1104.

Lund, S. P., M. Schwartz, L. Keigwin, and T. Johnson (2005), Deep-sea sediment record of the Laschamp geomagnetic field excursion ( 41,000 calendar years before present), J. Geophys. Res., 110, B04101, doi:10.1029/2003JB002943.

McCabe, C., R. Van der Voo, D. R. Peacor, C. R. Scotese, and R. Freeman (1983), Diagenetic magnetite carries ancient yet secondary remanence in some Paleozoic sedimentary carbonates, Geology, 11, 221-223, doi:10.1130/0091-7613(1983)11<221:DMCAYS >2.0.CO;2.

Mellars, P. (2006), A new radiocarbon revolution and the dispersal of modern humans in Eurasia, Nature, 439, 931-935, doi:10.1038/ nature04521.

Negrini, R. M., D. Erbes, K. Faber, A. Herrera, A. Roberts, A. Cohen, P. Wigand, and F. Foit Jr. (2000), A paleoclimate record for the past 250,000 years from Summer Lake, Oregon, USA. 1. Chronology and magnetic proxies for lake level, J. Paleolimnol., 24, 125-149, doi:10.1023/A:1008144025492.

Nowaczyk, N. R., H. W. Arz, U. Frank, J. Kind, and B. Plessen (2012), Dynamics of the Laschamp geomagnetic excursion from Black Sea sediments, Earth Planet. Sci. Lett., 351-352, 54-69, doi:10.1016/j.epsl.2012.06.050.

Olson, P., and U. R. Christensen (2002), The time-averaged magnetic field in numerical dynamos with non-uniform boundary heat flow, Geophys. J. Int., 151, 809-823, doi:10.1046/j.1365-246X.2002.01818.x.

Plenier, G., J.-P. Valet, G. Guérin, J.-C. Lefevre, M. LeGoff, and B. Carter-Stigliz (2007), Origin and age of the directions recorded during the Laschamp event in the Chaine des Puys, Earth Planet. Sci. Lett., 259, 414-431, doi:10.1016/j.epsl.2007.04.039.

Roberts, A. P. (2006), High-resolution magnetic analysis of sediment cores: Strengths, limitations and strategies for maximizing the value of long-core magnetic data, Phys. Earth Planet. Int., 156, 162-178, doi:10.1016/j.pepi.2005.03.021.

Roberts, A. P. (2008), Geomagnetc excursions: Knowns and unknowns, Geophys. Res. Lett., 35, L17307, doi:10.1029/2008GL034719.

Snowball, I., and R. Thompson (1990), A stable chemical remanence in Holocene sediments, J. Geophys. Res., 95, 4471-4479, doi:10.1029/ JB095iB04p04471.

Stuiver, M., P. J. Reimer, and R. W. Reimer (2014), CALIB 6.1.1 [WWW program and documentation].

Svensson, A., S. W. Nielsen, S. Kipfstuhl, S. J. Johnsen, J. P. Steffensen, M. Bigler, U. Ruth, and R. Rothlisberger (2005), Visual stratigraphy of the North Greenland Ice Core Project (North-GRIP) ice core during the last glacial period, J. Geophys. Res., 110, D02108, doi:10.1029/ $02004 J D 005134$.

Svensson, A., et al. (2008), A 60,000 year Greenland stratigraphic ice core chronology, Clim. Past., 4, 47-57, doi:10.5194/cp-4-47-2008.

Tauxe, L. (1993), Sedimentary records of relative paleointensity of the geomagnetic field: Theory and practice, Rev. Geophys., 31, 319-354, doi:10.1029/93RG01771.

Tauxe, L. (2009), Essentials of Paleomagnetism (Web Edition), 489 pp., University of California Press, Berkeley, Calif.

Valet, J.-P., and H. Valladas (2010), The Laschamp-Mono Lake geomagnetic events and the extinction of Neanderthal: A causal link or a coincidence?, Quat. Sci. Rev., 29, 3887-3893, doi:10.1016/j.quascirev.2010.09.010.

Valet, J.-P., G. Plenier, and E. Herrero-Bervera (2008), Geomagnetic excursions reflect an aborted polarity state, Earth Planet. Sci. Lett., 274, 472-478, doi:10.1016/j.epsl.2008.07.056.

Vazquez, J. A., and M. I. Lidzbarski (2012), High-resolution tephrochronology of the Wilson Creek Formation (Mono Lake, California) and Laschamp Event using 238U-Th SIMS dating of accessory mineral rims, Earth Planet. Sci. Lett., 357-358, 54-67, doi:10.1016/j. epsl.2012.09.013.

Wagner, G., J. Beer, C. Laj, C. Kissel, J. Masarik, R. Muscheler, and H.-A. Synal (2000), Chlorine-36 evidence for the Mono Lake event in the Summit GRIP ice core, Earth Planet. Sci. Lett., 181, 1-6, doi:10.1016/S0012-821X(00)00196-5.

Wardinski, I., and M. Korte (2008), The evolution of the core-surface flow over the last seven thousands years, J. Geophys. Res., 113, B05101, doi:10.1029/2007JB005024.

Wisniowiecki, M. J., R. Van der Voo, C. McCabe, and W. C. Kelly (1983), A Pennsylvanian paleomagnetic pole from mineralized Late Cambrian Bonneterre Formation, southeast Missouri, J. Geophys. Res., 88, 6540-6548.

Zic, M., R. M. Negrini, and P. E. Wigand (2002), Evidence of synchronous climate change across the Northern Hemisphere between the North Atlantic and the northwestern Great Basin, United States, Geology, 30, 635-638, doi:10.1130/0091-7613(2002)030<0635:EOSCCA >2.0.CO;2.

Zimmerman, S. H., S. R. Hemming, D. V. Kent, and S. Y. Searle (2006), Revised chronology for late Pleistocene Mono Lake sediments based on paleointensity correlation to the global reference curve, Earth Planet. Sci. Lett., 252, 94-106, doi:10.1016/j.epsl.2006.09.030. 